\title{
PENGEMBANGAN TRAINER PROGRAMMABLE LOGIC CONTROL (PLC) S7-1200 SEBAGAI MEDIA PEMBELAJARAN INSTALASI MOTOR LISTRIK DI SMK
}

\author{
Irman Edi Sarwono \\ Henry Ananta
}

\begin{abstract}
Abstrak: Tujuan penelitian adalah untuk mengembangkan media pembelajaran instalasi motor listrik, mengetahui kelayakannya, dan mengetahui pengaruh media pembelajaran terhadap peningkatan hasil belajar siswa. Penelitian ini menggunakan desain penelitian model ADDIE, dengan pendekatan kuantitatif desain eksperimen Quasi Experimental Design dengan model Nonequivalent Control Group Design. Hasil uji produk dinyatakan sangat layak. Peningkatan nilai rata-rata pretest dan posttest sebesar 20,20\% untuk kelompok control dan 33,20\% untuk kelompok eksperimen. Hasil analisis uji-t menunjukkan bahwa hasil pretest tidak memiliki perbedaan, sedangkan hasil posttest memiliki perbedaan. Hasil perhitungan uji gain diperoleh rata-rata gain sebesar 0,313 untuk kelas control dan 0,482 untuk kelas eksperimen. Berdasarkan uraian tersebut dapat disimpulkan bahwa penggunaan media pembelajaran trainer S7-1200 yang telah dikembangkan teruji efektif dan layak digunakan untuk pembelajaran pada mata pelajaran Instalasi Motor Listrik
\end{abstract}

Kata-kata Kunci: media pembelajaran, instalasi motor listrik

\begin{abstract}
Development of Programmable Logic Control (PLC) Trainer S7-1200 as a Learning Media for Electric Motors Installation Course in SMK. This research aims to develop a learning media for electric motor installation course, to assess the feasibility, and to identify the effect of the learning media on the student leaning outcomes improvement. This study used the ADDIE research design model, with a quantitative approach. The experimental design used a Quasi-Experimental Design with Nonequivalent Control Group Design model. The product feasibility result was declared as very feasible. The increase on the average score of pretest and posttest was $20.20 \%$ for the control group and $33.20 \%$ for the experimental group. The analysis using t-test showed that there was no significant difference on the pretest score, but there was a significant difference on the post-test score. The results of the gain test showed the average gain of 0.313 for the control class and 0.482 for the experimental class. Based on the results, it can be concluded that the use of the developed learning media S7-1200 trainer has been proved to be effective and suitable for learning in the Electric Motor Installation course.
\end{abstract}

Keywords: learning media, electric motor installation

$\mathrm{P}$ ramana, Nur'aini (2013:93) menyampaikan bahwa pendidikan meningkatkan kualitas sumber daya manusia. Keberhasilan proses pendidikan memegang peranan penting dalam upaya secara langsung akan berdampak pada

Irman Edi Sarwono adalah Mahasiswa Jurusan Teknik Elektro Universitas Negeri Semarang. Email: rmanlistrik@gmail.com. Henry Ananta adalah Dosen Jurusan Teknik Elektro Universitas Negeri Semarang. Alamat Kampus: Kampus Sekaran Gunungpati Semarang 50229. 
peningkatan kualitas sumber daya manusia tersebut. Salah satu indikator pendidikan yang baik adalah lulusan yang kompeten atau kompetensi lulusan. Kompetensi merupakn fungsi dari banyak variabel antara lain kemampuan peserta didik, kemampuan pendidik, fasilitas, manajemen dan perkembangan pengetahuan ilmiah dan teknologi serta seni.

Sekolah Menengah Kejuruan (SMK) sebagai salah satu pemegang peranan yang penting dalam penyiapan tenaga kerja dituntut untuk selalu dapat mengikuti kebutuhan pasar yang terus berkembang. Peraturan Pemerintah Republik Indonesia No. 29 Tahun 1990 tentang pendidikan menengah pasal 3 ayat 2 meyebutkan bahwa SMK mengutamakan penyiapan siswa untuk memasuki lapangan kerja serta mengembangkan sikap profesional.

Salafuddin dan Ananta (2013: 26) menyampaikan bahwa tenaga kerja mempunyai peranan dan kedudukan yang sangat penting sebagai pelaku dan tujuan pembangunan nasional. Sesuai dengan peranan dan kedudukan tenaga kerja, diperlukan pembangunan ketenagakerjaan untuk meningkatkan kualitas tenaga kerja dan peransertanya dalam pembangunan serta peningkatan perlindungan tenaga kerja dan keluarganya sesuai dengan harkat dan martabat kemanusiaan.

Kenyataan di lapangan menunjukkan bahwa keberadaan SMK saat ini dinilai masih kurang dalam penyiapan lulusannya sebagai tenaga siap kerja. Dani Wardani (Callan, 2003 dan Clarke, 2007) mensinyalir bahwa ada perbedaan tujuan antara dunia pendidikan dengan dunia industri karena dunia sekolah menginginkan lulusan yang memiliki nilai tinggi dalam waktu yang cepat sedangkan dunia industri menginginkan lulusan dengan kompetensi teknis dan sikap yang baik.

Proses pembelajaran di SMK menuntut siswa mempunyai tiga ranah yaitu kognitif, afektif, dan psikomotorik. SMK dituntut harus mampu menciptakan Sumber Daya Manusia (SDM) yang dapat beradaptasi dengan kemajuan ilmu pengetahuan dan teknologi. Dalam proses pembelajaran di SMK tugas utamanya adalah pencetak tenaga kerja yang siap pakai harus membekali peserta didik dengan pengetahuan dan ketrampilan yang sesuai dengan kompetensi program keahlian masing-masing.

Proses pembelajaran sendiri terdapat beberapa faktor yang dapat mempengaruhi kegiatan proses sistem pembelajaran, salah satu diantaranya adalah media pembelajaran yang menunjang. Media pembelajaran merupakan salah satu solusi untuk membuat pembelajaran lebih baik dan menarik. Hal ini sesuai dengan pendapat Nur'aini (2013:42) bahwa kegiatan belajar mengajar dengan dibantu oleh media akan menghasilkan proses dan hasil belajar yang lebih baik daripada tanpa bantuan media. Oleh karena itu, seorang pendidik harus dapat membuat media yang baik dan dapat menarik peserta didik untuk lebih antusias dalam mengikuti pembelajaran.

SMK Negeri 1 Magelang merupakan salah satu Sekolah Menengah Kejuruan di Jawa Tengah yang memiliki program keahlian Teknik Ketenagalistrikan dengan paket keahlian Teknik Instalasi Pemanfaatan Tenaga Listrik. Dalam kurikulum program keahlian Teknik Ketenagalistrikan terdapat mata pelajaran Instalasi Motor Listrik. Mata pelajaran Instalasi Motor Listrik khususnya kelas XII mempelajari tentang pemasangan dan pengendalian motor listrik secara teori maupun praktik menggunakan PLC (Programmable Logic Controller).

Standar kompetensi memasang komponen dan sirkit Programmable Logic Control (PLC) memiliki beberapa kompetensi dasar yang tercantum pada Tabel 1 yang merupakan silabus kompetensi Instalasi Motor Listrik untuk keperluan 
industri. Semua kompetensi dasar yang ada harus dikuasai oleh peserta didik.

Salah satu kriteria siswa dinyatakan menguasai kompetensi keahlian yaitu telah mengikuti dan lulus UKK (Uji Kompetensi Keahlian). UKK adalah bagian dari intervensi Pemerintah dalam menjamin mutu pendidikan pada satuan pendidikan Sekolah Menengah Kejuruan (SMK). Pelaksanaan UKK bertujuam untuk megukur pencapaian kompetensi siswa pada level tertentu sesuai Kompetensi Keahlian yang ditempuh selama masa pembelajaran di SMK. Berikut adalah data jumlah siswa peserta Uji Kompetensi Keahlian di SMK N 1 Magelang Jurusan Teknik Pemanfaatan Instalasi Tenaga Listrik tiga tahun terakhir.

Pada saat Praktik Pengalaman Lapangan (PPL) yang telah dilaksanakan pada sekolah tahun ajaran 2016/2017 diperoleh data bahwa hasil belajar peserta didik mata pelajaran Instalasi Motor Listrik yang ada di Jurusan Listrik SMK Negeri 1 Magelang rata-rata menunjukkan tingkat pemahaman yang kurang pada nilai praktik dan nilai teori, terutama pada nilai ujian praktik yang sering kurang dari nilai KKM (Kriteria Ketuntasan Minimal) yaitu 76. Berdasarkan observasi yang telah dilakukan di SMK Negeri 1 Magelang Jurusan Teknik Instalasi Pemanfaatan Tenaga Listrik pada tanggal 10 Januari 2018, diketahui bahwa dari 3 kelas dengan total 93 siswa hanya 33,3\% yang memenuhi KKM dan 66,6 \% masih berada dibawah KKM pada mata pelajaran instalasi motor listrik.

Dari data diatas peneliti menyimpulkan bahwa masih kurang minatnya siswa untuk mempelajari mata pelajaran instalasi motor listrik menggunakan Programmable Logic Control (PLC). Jadi, masih kurangnya pemahaman siswa dalam segi praktik maupin teori pada mata pelajaran instalasi motor listrik.

Hal ini disebabkan karena kurangnya media pembelajaran, keterbatasan alat praktik dan belum dimanfaatkannya media maupun peralatan baru yang sudah tersedia di Jurusan Listrik. Menurut Hamalik dalam Arsyad (2007:19) menjelaskan bahwa dengan menggunakan media pembelajaran dalam proses belajardapat membangkitkan keinginan dan minat yang baru, membangkitkan motivasi dan rangsangan kegiatan belajar serta dapat mempengaruhi psikologi siswa.

Oleh karena itu perlu adanya pengembangan media pembelajaran pada mata pelajaran instalasi motor listrik berupa trainer Programmable Logic Controller (PLC), diharapkan siswa mampu menguasai pengetahuan dan ketrampilan dalam pengaplikasian PLC. Disisi lain ditujukan untuk menunjang mutu dari lulusan SMK yang dituntut agar selalu dapat mengikuti kebutuhan dunia industri masa kini.

Berdasarkan permasalahan tersebut maka perlu dilakukan penelitian dengan judul "Pengembangan Trainer Programmable Logic Controller (PLC) S7-1200 sebagai Media Pembelajaran Instalasi Motor Listrik di SMK Negeri 1 Magelang."

\section{METODE}

Model yang digunakan dalam penelitian ini adalah penelitian pengembangan dengan pendekatan kuantitatif yang berorientasi pada pengembangan produk. Metode penelitian dan pengembangan (Research \& Development) adalah metode penelitian yang digunakan untuk menghasilkan produk tertentu dan menguji keefektifan produk (Sugiyono. 2012: 407). Pengembangan yang dilakukan merupakan pengembangan media pembelajaran dari mata pelajaran instalasi motor listrik kelas XII berupa trainer Programmable Logic Control (PLC) S71200.

Pengembangan ini menggunakan desain penelitian model ADDIE, dengan 
menggunakan pendekatan kuantitatif. Kata ADDIE merupakan akronim dari sebuah model desain instruksional umum, yang terdiri dari: Analyze, Design, Develop, Implement, dan Evaluate (Gordon, 2007: 2). Welty, 207 menyatakan bahwa model ADDIE adalah salah satu model yang paling umum digunakan dibidang desain instruksional panduan untuk memproduksi sebuah desain yang efektif. Model ADDIE terdiri atas lima tahapan yaitu Analysis, Design, Development, implementation, and evaluations (Prasetyo, 2012:4). Kelima tahapan itu diuraikan sebagai berikut: (1) Analysis model ADDIE pada tahap ini dilakukan kegiatan pendahuluan di SMK Negeri 1 Magelang. Penelitian pendahuluan meliputi kegiatan: analisis lapangan dan analisis pustaka. (2) Design yaitu rancangan yang masih bersifat konseptual dan merupakan suatu proses pengembangan tujuan, merancang materi pembelajaran, strategi pembelajaran, tampilan media pembelajaran, merancang alat evaluasi (tes).

(3) Development adalah proses persiapan bahan pengajaran untuk merealisasikan rancangan produk yang siap diimplementasikan. Produk yang dikembangakan nantinya akan dievaluasi untuk kemudian disempurnakan. (4) Implementation adalah proses penggunaan produk yang telah dikembangkan pada situasi yang nyata. Proses penerapan media pembelajaran dilakukan tes evaluasi guna mengukur kemampuan siswa sebelum dan sesudah menggunakan media pembelajaran. Pada tahap ini juga untuk mengetahui tanggapan siswa terhadap media pembelajaran berupa trainer PLC S7-1200. (5) Evaluation mencakup hasil akhir dari tahapan ini yang merupakan laporan evaluasi dan revisi dari masingmasing tahapan sebagai perbaikan media pembelajaran.

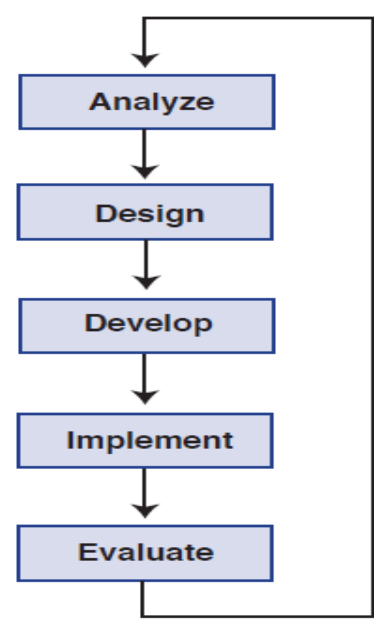

Gambar 1. Alur Model Penelitian ADDIE (Sumber: Welty, 2007:10)

Dari Gambar 1 alur model penelitian diatas, dapat disimpulkan bahwa model pengembangan ADDIE merupakan model yang tepat untuk mengembangkan media pembelajaran instalasi motor listrik. Unsur-unsur pada model ADDIE dilakukan secara berurutan, setiap elemen bergantung pada keberhasilan fase sebelumnya. Selain itu, model ADDIE merupakan model umpan terbalik berulang yang berarti hasil fase evaluasi diberikan umpan balik, menutup lingkaran dan memberikan fasilitas penyempurnaan lebih lanjut (Welty, 2007:3).

Desain uji coba produk untuk kelayakan media yaitu dengan menggunakan validasi dari para ahli, baik ahli media ataupun ahli materi. Selanjutnya untuk uji coba yang dilakukan untuk mengetahui keefektifan digunakan Quasi Experimental Design dengan model Nonequivalent Control Group Design. Penelitian menggunakan desain ini terdapat dua kelompok yang sudah dipilih, kemudian diberikan pretest untuk mengetahui kondisi awal kelompok control dan kelompok eksperimen, kemudian diberi posttest untuk mengetahui perbedaan hasil perlakuan yang telah dilakukan antara kelompok control maupun kelompok eksperimen (Sugiyono 2016:116) 


\section{HASIL}

Setelah produk selesai dikembangkan, dilakukan uji kelayakan produk oleh validator ahli materi dan ahli media dengan rasional judgement. Uji kelayakan produk ini bertujuan untuk mengetahui tingkat kelayakan produk sebelum diujicobakan kepada peserta didik. Berikut ini data uji kelayakan produk yang dikembangkan dan divalidasi oleh ahli media dan ahli materi.

Data yang telah diperoleh dari masing-masing ahli, kemudian dilakukan analisis uji kelayakan untuk mengetahui kelayakan dari media pembelajaran yang dikembangkan. Berikut ini hasil analisis data uji kelayakan produk oleh ahli media dan ahli materi trainer PLC S7-1200.

Pada Tabel 1 menunjukkan hasil penilaian ahli media dalam menguji kelayakan trainer PLC-1200 yang telah dikembangkan. Analisis data diperoleh dengan perhitungan sesuai rumus kemudian ditransformasikan ke dalam tabel skala persentase penilaian. Berdasarkan perhitungan tersebut, penilaian ahli media menunjukkan hasil rata-rata sebesar 85.9\% dengan kriteria "Sangat Layak". Sehingga dapat disimpulkan secara keseluruhan alat peraga dinyatakan "Sangat Layak".

Pada tabel 2 menunjukkan hasil penilaian ahli materi dalam menguji kelayakan trainer S7-1200 yang telah dikembangkan. Berdasarkan perhitungan tersebut, penilaian ahli materi menunjuk- kan hasil rata-rata sebesar $91,30 \%$ dengan kriteria sangat layak.

Berdasarkan hasil pretest dan posttest baik kelas kontrol dan kelas eksperimen terdapat peningkatan nilai rata-rata, namun peningkatan yang terjadi pada kelas kontrol dan eksperimen berbeda. Peningkatan pada kelas kontrol sebesar $41,30 \%$ sedangkan peningkatan rata-rata pada kelas eksperimen sebesar 45,50\%. Secara garis besar peningkatan pada kelas eksperimen lebih tinggi dibanding peningkatan pada kelas kontrol. Peningkatan nilai rata-rata pretest dan posttest adalah dapat dilihat pada Gambar2.

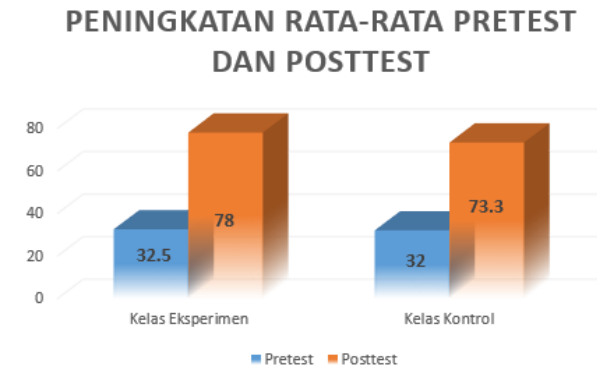

Gambar 2. Peningkatan Rata-rata Pretest dan Posttest

\section{PEMBAHASAN}

Pengembangan produk akhir menghasilkan media pembelajaran trainer S71200. Trainer S7-1200 DC/DC/DC memiliki sumber tegangan input 100240VAC 0.85A keluaran output 24VDC $1.5 \mathrm{~A}$ meliputi 14 switch input, 10 chanel

Tabel 1. Hasil Penilaian Ahli Media

\begin{tabular}{ccccc}
\hline No & Ahli Media & Jumlah skor & Skor maksimal & Presentase \% \\
\hline 1 & Drs. Sri Sukamta, M.Si. & 56 & 64 & $87,5 \%$ \\
2 & Khoirudin Fathoni, S.T., M.T & 54 & 64 & $84,9 \%$ \\
\hline \multicolumn{2}{r}{ Total } & $\mathbf{1 1 0}$ & $\mathbf{1 2 8}$ & $\mathbf{8 5 , 9 \%}$ \\
\hline
\end{tabular}

Tabel 2. Hasil Penilaian Ahli Materi

\begin{tabular}{ccccc}
\hline No & Ahli Media & Jumlah skor & Skor maksimal & Presentase \% \\
\hline 1 & Tatyantoro Andrasto, S.T., M.T. & 47 & 52 & $90,4 \%$ \\
2 & Mamik Yunanto, S.Pd.T & 48 & 52 & $92,3 \%$ \\
\hline & Total & $\mathbf{9 5}$ & $\mathbf{1 0 2}$ & $\mathbf{9 1 , 3 \%}$ \\
\hline
\end{tabular}


output with indicator, 1 selector switch input, 3 push-button, 1 buzzer, 1 switch emergency, 3 magnetic contactor, 3 relay 24VDC completely jobsheet, dan automatic gate module.

Switch input digunakan untuk mengkontrol on-off digital input dari luar perangkat PLC dan indikator LED berfungsi sebagai tanda operand output PLC yang bekerja. Adapun selector switch bisa menjadi alternatif pilihan penggunaan program kendali secara manual ataupun otomatis. Push button switch (sakelar tombol tekan) adalah perangkat atau sakelar sederhana yang berfungsi untuk menghubungkan atau memutuskan aliran arus listrik dengan system tekan unlock (tidak mengunci). Sedangkan emergency switch digunakan untuk pemutus arus dalam kondisi darurat atau karena ada sesuatu hal yang tidak diinginkan dalam rangkaian tersebut. Magnetic Contactor merupakan sebuah komponen penghubung atau kontak dengan kapasitas besar dan menggunakan daya minimal (relay kapasitas besar). Relay 24 VDC sebagai kontrol tegangan rangkaian dengan sinyal yang rendah. Salah satu untuk memacu minat siswa, maka peneliti membuat modul pembelajaran aplikasi penerapan PLC berupa miniature pintu gerbang otomatis. Diharapkan siswa mampu membuka wawasannya untuk tertarik mengembangkan kemampuan dirinya. Trainer PLC S7-1200 dilengkapi dengan buku panduan penggunaan media pembelajaran diawali dari pengenalan PLC, pengalamatan $\mathrm{I} / \mathrm{O}$, pemrograman ladder diagram, pengenalan layout trainer serta wiring penggunaan trainer.

Berdasarkan uji kelayakan produk yang dilakukan oleh ahli media dan ahli materi dari Dosen Teknik Elektro FT UNNES dan Guru Jurusan TPTL SMK Negeri 1 Magelang menunjukkan tingkat kelayakan rasional judgement sebesar $85,90 \%$ diperoleh dari ahli media dan $91,30 \%$ diperoleh dari ahli materi sehing- ga berdasarkan tabel skala persentase penilaian ahli dinyatakan Sangat layak. Kondisi ini didapat berdasarkan penilaian ahli media yang mencakup aspek tampilan, konstruksi, kemudahan penggunaan dan manual book. Sedangkan ahli materi hal tersebut dilihat dari aspek prinsip kerja, komponen dan fungsinya, rangkaian dan cara kerjanya, serta manual book. Oleh karena itu media pembelajaran trainer S7-1200 ini telah memenuhi kriteria dan dinyatakan sudah layak digunakan dalam pembelajaran dan dapat dijadikan alat untuk pengambilan data.

Trainer S7-1200 diujicobakan kepada responden yaitu siswa kelas XII LA dan XII LC tahun pelajaran 2018/2019 SMK Negeri 1 Magelang sejumlah 60 siswa yang telah mendapat materi pokok bahasan instalasi motor listrik. Pengujian dilakukan untuk mengetahui peningkatan hasil belajar menggunakan pretest dan posttest. Hasil pretest kelas kontrol dengan rata-rata sebesar 60.80 dan kelas eksperimen 59.20. Kemudian dilakukan perlakuan (treatment) sebelum pengambilan data posttest, perlakuan ini bertujuan untuk memberikan materi tentang instalasi motor listrik sesuai dengan trainer yang sudah dikembangkan. Pada kelas kontrol diperoleh nilai posttest rata-rata 73.07. Pada kelas eksperimen, pengambilan nilai menggunakan alat yang telah dikembangkan diperoleh hasil sebesar 78.87. Oleh karena itu hasil belajar siswa mengalami peningkatan sebesar $20,20 \%$ pada kelas kontrol dan 33,20\% pada kelas eksperimen dengan kategori "sedang" $N$-Gain sebesar 0,313 pada kelas kontrol dan 0,482 pada kelas eksperimen. Peningkatan hasil belajar dapat dipengaruhi oleh kelebihan media pembelajaran trainer yang dikembangkan yaitu adanya module pintu gerbang otomatis yang memusatkan perhatian siswa untuk bisa lebih mengembangkan kemampuan dirinya, dari sini siswa mengetahui penerapan aplikasi PLC yang sebenarnya. 
Hal ini selaras dengan pendapat Sudjana (2013:22) menyatakan bahwa pemusatan perhatian siswa dalam pembelajaran juga menjadi faktor penting di dalam proses belajar.

Berdasarkan uraian tersebut dapat disimpulkan bahwa penggunaan media pembelajaran trainer S7-1200 yang dikembangkan teruji efektif sehingga layak digunakan untuk pembelajaran pada mata pelajaran Instalasi Motor Listrik pokok bahasan sistem pengendali otomatis berbasis PLC, dibuktikan dengan peningkatan hasil belajar siswa setelah menggunakan peraga pembelajaran yang telah dikembangkan.

\section{SIMPULAN DAN SARAN}

Berdasarkan pembahasan hasil penelitian tentang media pembelajaran trainer PLC S7-1200 dapat disimpulkan bahwa pembelajaran trainer PLC S7-1200 dikembangkan dapat meningkatkan pemahaman siswa. Hal tersebut dibuktikan dengan adanya perbedaan hasil belajar antara kelas kontrol yang tidak menggunakan media trainer dan kelas eksperimen yang menggunakan media pembelajaran trainer S7-1200.

Peningkatan nilai rata-rata yang terjadi pada kelas eksperimen lebih tinggi dibandingkan peningkatan nilai rata-rata yang terjadi pada kelas kontrol. Berdasarkan data yang diperoleh, peningkatan rata-rata nilai pretest dan posttest untuk kelas kontrol sebesar 41,30\%, sedangkan kelas eksperimen sebesar $45,50 \%$. Adapun peningkatan hasil belajar peserta didik melalui uji n-gain mengalami peningkatan dalam kategori "sedang" sebesar 0,60 untuk kelas kontrol dan 0,67 untuk kelas eksperimen. Selanjutnya, untuk memaksimalkannya, alat peraga ini perlu dipergunakan secara mandiri oleh para siswa, sehingga peningkatan hasil pembelajaran dapat lebih maksimal.

\section{DAFTAR RUJUKAN}

Arsyad, A. 2007. Media Pembelajaran. Jakarta: PT Raja Grafindo Persada.

Callan,VJ. 2003. Generic Skills Understanding Vocational Education and Training Teacher and Student Attitudes. Adelaide: NCVER

Clarke, M. 2007. Understanding and Managing Employability in Changing Career Contexts. Journal of European Industrial Training 32 (4): 258-284.

Nur'aini, F. dkk. 2013. Pengembangan Media Berbasis Multimedia Interaktif untuk Meningkatkan Pemahaman Siswa Man 2 Batu Materi Kingdom Animalia. Jurnal Pendidikan Biologi Indonesia. 1(1): 3546.

Prasetyo, Z.K. 2012. Research and Development Pengembangan Berbasis Penelitian. Yogyakarta: FMIPA, UNY.

Salafuddin, M. \& Ananta, H. 2013. Implementasi Sistem Manajemen Keselamatan dan Kesehatan kerja di PT PLN (Persero) Area Pengatur Distribusi Jawa Tengah \& D.I.Yogyakarta dalam Upaya Peningkatan Mutu dan Produktivitas Kerja Karyawan. Jurnal Teknik Elektro Volume, 5(1), Universitas Negeri Semarang.

Sudjana, N. 2013. Dasar-dasar Proses Belajar Mengajar. Bandung: Sinar Baru Algensindo.

Sugiyono. 2012. Statistika Untuk Penelitian. Bandung: Alfabeta.

Sugiyono. 2016. Metode Penelitian Kuantitatif, Kualitatif, dan $R \& D$. Bandung: Alfabeta..

Welty, G. 2007. The ADDIE Model, and Instructional Generic Design Model Journal of GXP Compliance. Special Edition: 1-69. 